\title{
The erythrocyte membrane in kwashiorkor
}

\author{
By W. A. COWARD \\ Medical Research Council Child Nutrition Unit, PO Box 6717, \\ Kampala, Uganda
}

(Received I May 1970-Accepted $9 \mathfrak{f u l y}$ 1970)

\begin{abstract}
I. Erythrocytes from Ugandan children with untreated kwashiorkor had membranes containing larger amounts of lecithin than erythrocytes collected during the recovery phase.

2. The passive permeability of the erythrocyte membrane to glycerol and thiourea was reduced in kwashiorkor and returned to a more normal value on treatment.

3. The results are discussed in the light of similar findings of high erythrocyte lecithin concentrations in various liver diseases.
\end{abstract}

Abnormalities of lipid metabolism in kwashiorkor are well documented. In Uganda, as elsewhere, frequent findings are fatty infiltration of the liver and a reduction in the quantity of serum lipids (Schwarz \& Dean, 1957). The concentrations of both the $\alpha$ - and $\beta$-lipoproteins are also reduced, the $\beta$-lipoproteins possibly more so (Cravioto, De la Pena \& Burgos, 1959; Mönckeberg, 1968).

Lipids, in particular phospholipids, are also essential components of membrane systems, and although there has been speculation about possible changes in these structures as a result of severe protein-calorie malnutrition, this has not yet been investigated. Membrane changes have, however, been described in other conditions where there are defects in lipid metabolism. The phospholipid composition of erythrocyte membranes is abnormal in a number of liver diseases (Nye \& Marinetti, 1967; Boon, Broekhuyse, van Munster \& Schretlen, I969), in Niemann-Pick disease (Balint, Nyhan, Lietman \& Turner, 196r), in Tay-Sachs disease (Balint, Spitzer \& Kyriakides, 1963), in various other lipidoses (Hooghwinkel, van Gelderen \& Staal, r969) and in acanthocytosis (Ways, Reed \& Hanahan, I963).

This study was carried out in order to investigate the possibility that malnutrition, leading to kwashiorkor, might result in structural and functional changes in cell membranes. Because they were readily available, erythrocytes were used to provide the membrane material for phospholipid analysis. Although erythrocytes must be regarded as somewhat specialized structures, the importance of phospholipids is common to all biological membranes; changes in erythrocyte phospholipids may indicate changes in other cells.

Since the relative amounts of the different phospholipid components in erythrocyte membranes are thought to be associated with their passive permeability properties (van Deenen, 1965), measurements were also made of the velocity of penetration of glycerol and thiourea into the erythrocytes.

The chemical analyses and permeability studies were made on the children when they were admitted to hospital with kwashiorkor and then at subsequent stages during treatment. 


\section{EXPERIMENTAL}

Eleven children were studied; all suffered from oedematous malnutrition (kwashiorkor) and their serum albumin concentrations on admission were less than I $7 \mathrm{~g} / \mathrm{I} 00 \mathrm{ml}$. None of the children exhibited a sickle cell anaemia. They were treated as described by Staff (1968).

Fasting venous blood samples were collected, into tubes containing either heparin or sequestrine on admission, after $2-3$ weeks treatment and near discharge (5-6 weeks). The heparinized blood was used for the preparation of erythrocyte ghosts and for the determination of concentrations of plasma albumin and phospholipid. Blood cell counts and mean corpuscular volume were determined and permeability studies were made on the sequestrinized sample. Cell counts were made and mean corpuscular volume was determined with a Coulter Counter Model F, incorporating a mean cell volume computor (Coulter Electronics, Dunstable, Bedfordshire).

Erythrocyte ghosts ${ }^{1} \mathrm{O}^{10}-\mathrm{IO}^{11}$ were prepared by haemolysis in phosphate buffer of low osmolarity by the method of Dodge, Mitchell \& Hanahan (1963). Lipid was extracted from the erythrocyte ghosts with chloroform and methanol 2:1 (v/v) (Folch, Lees \& Stanley, 1957). The suspension of cell ghosts was slowly dripped into the mixture and constantly stirred to avoid the formation of a congealed lump as found by Dawson, Hemington \& Lindsay (1960). Individual phospholipids were fractionated on thin layers of silica gel H (Merck, Darmstadt, Germany), previously washed to remove any contaminating phosphate as described by Parker \& Peterson (1965). A solvent system consisting of chloroform:methanol:ammonia (sp.gr. 0.9 ): water $(65: 35: 3: 1)$ gave a satisfactory separation of the four major phospholipid classes, lecithin (phosphatidyl choline), sphingomyelin, phosphatidyl serine and phosphatidyl ethanolamine. These lipid components were made visible with iodine vapour and ringed.

Lipids were extracted from plasma by the method of Zöllner \& Wolfram (1962).

Lipid phosphorus was determined in total plasma lipid, in erythrocyte-ghost lipid and in chromatogram 'scrapings' containing the individual phospholipids by the method of Marinetti (1962). Concentrations of plasma albumin were estimated by an automated colorimetric micro-method (Coward, Sawyer \& Whitehead, 1970).

Measurements of the permeability of erythrocytes to glycerol and thiourea (Jacobs, Glassmann \& Parpart, 1950) were made by rapidly adding $3 \mathrm{ml}$ of isotonic solutions of these substances to $20 \mu \mathrm{l}$ whole blood contained in a spectrophotometer cell, with O-I path length of $\mathrm{I} \mathrm{cm}$, at $20^{\circ}$. The decrease in turbidity of the cell suspension which occurred as the cells haemolysed was measured in a Unicam SP 800 recording spectrophotometer at $650 \mathrm{~nm}$. The time taken for $75 \%$ haemolysis was determined.

\section{RESULTS}

Recovery from kwashiorkor in the eleven children followed a typical course; plasma albumin and total phospholipid concentrations rose (Table I). Schwarz \& Dean (1957) reported a rapid increase in phospholipid concentration which reached a maximum after about I week of treatment. Failure to observe this peak in my experiment occurred presumably because the second blood sample was not taken until 
week 2-3. Red cell counts also increased during the experimental period as a whole but the rise over the first $2-3$ weeks was not statistically significant. This was possibly because red cell counts on admission can be misleadingly high owing to haemoconcentration and a fall is often observed during the ist week of treatment as oedema is lost and the blood volume expands. Mean corpuscular volume decreased during the

Table I. Erythrocyte count, mean erythrocyte surface area, plasma albumin and plasma phospholipid concentration in eleven children with kwashiorkor, on admission to hospital and at different stages during their recovery

\begin{tabular}{|c|c|c|c|c|c|c|c|c|}
\hline \multirow{2}{*}{$\begin{array}{l}\text { Stage } \\
\text { in } \\
\text { treat- } \\
\text { ment }\end{array}$} & \multicolumn{2}{|c|}{$\begin{array}{c}\text { Erythrocyte } \\
\text { count } / \mu 1 \\
\left(\times 10^{-6}\right)\end{array}$} & \multicolumn{2}{|c|}{$\begin{array}{c}\text { Erythrocyte } \\
\text { surface area } \uparrow \\
\left(\mu \mathrm{m}^{2}\right)\end{array}$} & \multicolumn{2}{|c|}{$\begin{array}{l}\text { Plasma albumin } \\
(\mathrm{g} / \mathrm{r} 00 \mathrm{ml})\end{array}$} & \multicolumn{2}{|c|}{$\begin{array}{c}\text { Plasma } \\
\text { phospholipid } \\
\text { (mg } \mathrm{P} / \mathrm{r} 00 \mathrm{ml} \text { ) }\end{array}$} \\
\hline & Mean & $\mathrm{SE}$ & Mean & $\mathrm{SE}$ & Mean & $\mathrm{SE}$ & Mean & $\mathrm{SE}$ \\
\hline Admission & 3.37 & 0.21 & I $4 \mathrm{I}$ & 4 & $\mathrm{I} \cdot 5$ & $O \cdot I$ & 3.9 & 0.6 \\
\hline $\begin{array}{l}2-3 \text { weeks } \\
5-6 \text { weeks }\end{array}$ & $\begin{array}{l}3.60 \\
4.13\end{array}$ & $\begin{array}{l}0.09 \text { NS } \\
0.17^{*}\end{array}$ & - & $\overline{4^{* *}}$ & $\begin{array}{l}3.1 \\
3.5\end{array}$ & $\begin{array}{l}0.1 * * * \\
0.1 * * * *\end{array}$ & $\begin{array}{l}6.0 \\
5.8\end{array}$ & $0.5^{* * * *}$ \\
\hline
\end{tabular}

Values significantly different from admission values by the paired $t$ test: ${ }^{*} P<0.05 ; * * P<0.01$; ***P $<0.001$.

NS, not significant.

+ Calculated from mean erythrocyte volumes on the assumption that the cells were short cylinders with a constant height of $1 \cdot 8 \mu \mathrm{m}$ (Emmons, 1927 ).

Table 2. Erythrocyte ghost phospholipids ( $m g P \times \mathrm{IO}^{-13} /$ cell) in eleven children with kwashiorkor, on admission to hospital and at different stages during their recovery, and in three normal young adult Africans

\begin{tabular}{|c|c|c|c|c|c|c|}
\hline \multirow{2}{*}{$\begin{array}{l}\text { Stage in } \\
\text { treatment }\end{array}$} & \multicolumn{2}{|c|}{$\begin{array}{c}\text { Total } \\
\text { phospholipid }\end{array}$} & \multicolumn{2}{|c|}{ Lecithin } & \multicolumn{2}{|c|}{ Sphingomyelin } \\
\hline & Mean & $\mathrm{SE}$ & Mean & $\mathrm{SE}$ & Mean & $\mathrm{SE}$ \\
\hline Admission & 136 & 3 & 45 & 2 & 24 & $\mathrm{x}$ \\
\hline $2-3$ weeks & 125 & $4^{* * *}$ & 37 & $2 * * *$ & $2 \mathrm{I}$ & $I^{*}$ \\
\hline 5-6 weeks & IIO & $3 * * *$ & 29 & I*** & 20 & I* \\
\hline Young adult Africans & 104 & 4 & 30 & $\mathbf{I}$ & I 8 & $\mathbf{I}$ \\
\hline & \multicolumn{2}{|c|}{$\begin{array}{l}\text { Phosphatidyl } \\
\text { ethanolamine }\end{array}$} & \multicolumn{2}{|c|}{$\begin{array}{l}\text { Phosphatidyl } \\
\text { serine }\end{array}$} & \multicolumn{2}{|c|}{$\begin{array}{l}\text { Phospholipid not } \\
\text { accounted for }\end{array}$} \\
\hline $\begin{array}{l}\text { Stage in } \\
\text { treatment }\end{array}$ & Mean & SE & Mean & SE & Mean & $\mathrm{SE}$ \\
\hline Admission & $4 I$ & $\mathrm{I}$ & 9 & I & I7 & 2 \\
\hline 2-3 weeks & 40 & I NS & 9 & I NS & 17 & I $\mathrm{N}$ \\
\hline 5-6 weeks & 39 & I NS & 9 & I NS & I3 & $I^{*}$ \\
\hline Young adult Africans & 34 & 3 & 8 & 2 & 14 & I \\
\hline
\end{tabular}

Values significantly different from admission values by the paired $t$ test: ${ }^{*} P<0.05 ; * * P<0.01$; ***P< o.00I.

NS, not significant.

investigation. The corpuscular surface area was calculated from the volume measurements as it was considered that this measurement could have some bearing on the interpretation of the amounts of phospholipid found in the erythrocyte membrane. Slightly smaller cells might contain less phospholipid.

Marked changes occurred in the phospholipid composition of the erythrocyte 
ghosts during the experimental period (Table 2). A decrease in total phospholipid content was observed and it was significant when expressed either in terms of numbers of cells or per unit cell surface area $(P<0.001)$. The major factor contributing to this fall was a big decrease in the amount of lecithin. This was still significant $(P<0.00 \mathrm{I})$ when differences in cell surface areas were taken into account. No changes occurred in the cephalin fractions, phosphatidyl ethanolamine or phosphatidyl serine. A small decrease was seen in the sphingomyelin concentration per cell but it was not significant when surface areas were considered. It should be noted that any lysolecithin present was analysed as sphingomyelin. Decreases in this derivative of lecithin might account for some of the changes in the sphingomyelin fraction. Not all the lipid phosphorus in erythrocytes was contained in the four major chromatographic bands. Table 2 also shows values for the lipid phosphorus not accounted for; this, too, showed a fall in concentration per cell during treatment. Taking into account the alterations in cell surface area rendered this difference statistically not significant.

Table 3. Times of $75 \%$ haemolysis of erythrocytes in isotonic solutions of glycerol and thiourea in eleven children with kwashiorkor, on admission to hospital and at different stages during their recovery, and in three normal young adult Africans

\begin{tabular}{|c|c|c|c|c|}
\hline \multirow[b]{2}{*}{ Stage in treatment } & \multicolumn{2}{|c|}{ Glycerol } & \multicolumn{2}{|c|}{ Thiourea } \\
\hline & Mean & SE & Mean & SE \\
\hline Admission & $3^{8}$ & 4 & I09 & 6 \\
\hline $2-3$ weeks & 27 & $2 *$ & 93 & $4^{*}$ \\
\hline $5-6$ weeks & 23 & $2 * * *$ & 86 & $3 * *$ \\
\hline Young adult Africans & $2 I$ & 3 & 86 & 3 \\
\hline
\end{tabular}

Values significantly different from admission values by paired $t$ test: ${ }^{*} P<0.05$; $* P<0.01$; $* * * P$ $<0.001$.

The phospholipid composition of the erythrocytes of three young East African technicians was also measured and the results are given in Table 2 . The values showed little scatter and were very similar to those found in the children after successful treatment.

Times taken for the $75 \%$ haemolysis of erythrocytes in isotonic solutions of glycerol and thiourea are shown in Table 3. These times indicated that the permeability of erythrocytes to both substances was low on admission but increased with treatment. On discharge, the $75 \%$ haemolysis times in the children closely resembled those found in the three young adult Africans.

\section{DISCUSSION}

The results showed that changes occurred in the phospholipid composition of erythrocytes during treatment for kwashiorkor: the total phospholipid content per cell fell and the fall was almost completely due to a reduction in the amount of the lecithin fraction. Furthermore, the chemical composition at the end of treatment was very similar to that of erythrocytes from normal young adult Africans. Thus, it seems that Ugandan children with kwashiorkor make erythrocyte membranes with an abnormally high lecithin content. 
This finding might seem surprising, since children living on low-protein diets inevitably ingest reduced amounts of choline and its methyl donor precursor, methionine. Choline is the nitrogenous base in lecithin and sphingomyelin; membranes with a greater proportion of the cephalins, containing serine or ethanolamine, might have been expected. However, erythrocytes with a high lecithin content have been reported in a variety of liver diseases, including obstructive jaundice, alcoholic cirrhosis, infective hepatitis and diabetes with lipaemia (Nye \& Marinetti, 1967; Boon et al. I969). In the seventeen subjects described by the two groups of workers cited, the lecithin content was raised in fifteen. The average increase over control concentrations was $150 \%$, the same as in the study described here.

It would seem, therefore, that erythrocyte membranes with a high lecithin content can arise in a variety of diseases where liver lesions are the common feature. Whether or not this means that the liver is a site of synthesis of some of the phospholipid units which are eventually incorporated into erythrocyte membranes remains to be seen. Nye \& Marinetti (1967) did suggest that erythrocyte lecithin content might be correlated with the plasma concentration of this phospholipid, but, of eleven of their patients with high lecithin concentrations in the cells, four had decreased rather than increased plasma concentrations. Of the four patients described by Boon et al. (I969), two had low serum lecithin concentrations and in the other two the values were higher. Perhaps it would be more profitable to look for an explanation of changes in erythrocyte phospholipid concentrations in the metabolism of phospholipids in the liver or, alternatively, in the bone-marrow.

Why did the lecithin content of the erythrocytes fall with treatment? Since red cells themselves do not synthesize phospholipid, the most likely explanation is that the cells formed during the period of malnutrition gradually became replaced by new cells. Lanzkowsky, McKenzie, Katz, Hoffenberg, Friedman \& Black (1967), working in South Africa, showed that the half-life of erythrocytes was greatly reduced in children with kwashiorkor. It varied from 3 to $20 \mathrm{~d}$ with a mean of $\mathrm{I2}$. If this is also true for Ugandan children, it can be calculated that less than $10 \%$ of the original cell population would survive beyond 6 weeks. Furthermore, there was a rise in red cell concentration during treatment, and probably the total blood volume also increased. Thus, it is likely that as much as $95 \%$ of the erythrocyte membranes at the end of the study were synthesized during the recovery period and that these had a normal lecithin content. There is a further possibility that some exchange of phospholipid units might have occurred between the erythrocyte membranes and the plasma. The existence of such a process has been proposed by Reed (1959). However, there is no evidence in the results of an increase in the other phospholipid components, which would have occurred if the fall in lecithin had been due to an exchange reaction. It may be argued that the change in lecithin content of the erythrocyte membranes during treatment was due to contamination of the sample with reticulocytes. This is unlikely, however, since Ways et al. (1963) showed there was no difference in phospholipid content between cell membranes prepared from normal individuals and those from patients with a very high reticulocytosis (10-23\%). Furthermore, the reticulocyte count in untreated Ugandan children is always low, less than $1 \%$; it rises to $5-8 \%$ around day $\mathrm{I}_{4}$ of treatment and then falls to a more normal value before 
discharge (Allen \& Dean, 1965). There was no apparent relationship between these variations in reticulocyte count and the lecithin content of the isolated erythrocyte ghosts.

Had the high lecithin content of the erythrocyte membranes any functional significance? The permeability studies indicated that this might have been so. Increased times of haemolysis of the cells to glycerol and thiourea were associated with raised lecithin values; as the latter fell, more normal times were observed. It is usually assumed that differences in the time taken for $75 \%$ haemolysis demonstrate changes in passive permeability, but it is possible that a membrane with a higher lecithin content might rupture less easily, thus making the interpretation more difficult. Of course this type of study is biologically artificial, but Roelofsen, Gier \& van Deenen (1964) suggested that the passive permeability behaviour of an erythrocyte membrane was a function of different degrees of cohesion between lipids and proteins. Studies in different species of mammal have demonstrated correlations between permeability properties of erythrocyte membranes and their phospholipid composition (van Deenen, I965).

In relation to the present findings of decreased diffusion rates, it is interesting to note that Lanzkowsky et al. (1967) reported a decreased osmotic fragility in the erythrocytes of children with kwashiorkor. Furthermore, similar observations have been made in patients with hepatitis and obstructive jaundice (Pitcher \& Williams, I963). It is tempting to speculate that this decreased osmotic fragility might be due to the high lecithin content of the erythrocytes in these diseases (Nye \& Marinetti, I967; Boon et al. 1969).

The results reported here will have a greater significance if similar changes can be demonstrated in the membrane structures of the cells of other organs and tissues. Biochemical reactions at the cellular level depend on the structural integrity of the cell. Changes in membrane structure may have widespread metabolic consequences which may not be obvious from simple enzyme assays in vitro.

The author thanks Dr R. G. Whitehead for his interest in the work and advice in writing this paper. Acknowledgements are also due to the medical staff for the provision of blood samples, Mr J. B. Kiwanuka for albumin determinations and $\mathrm{Mr}$ A. S. Makwaya for other technical assistance.

\section{REFERENCES}

Allen, D. M. \& Dean, R. F. A. (1965). Trans. R. Soc. trop. Med. Hyg. 59, 326.

Balint, J. A., Nyhan, W. L., Lietman, P. \& Turner, D. A. (1961). F. Lab. clin. Med. 58, 548.

Balint, J. A., Spitzer, H. L. \& Kyriakides, E. C. (1963). F. clin. Invest. 42, I66r.

Boon, J., Broekhuyse, R. M., van Munster, P \& Schretlen, E. (1969). Clinica chim. Acta 23, 453.

Coward, D. G., Sawyer, M. B. \& Whitehead, R. G. (1970). Am. F. clin. Nutr. (In the Press.)

Cravioto, J., De La Pena, C. L. \& Burgos, G. (1959). Metabolism 8, 722.

Dawson, R. M. C., Hemington, N. \& Lindsay, D. B. (I960). Biochem. F. 77, 226.

Dodge, J. T., Mitchell, C. \& Hanahan, D. J. (1963). Archs Biochem. Biophys. roo, I 19.

Emmons, W. F. (1927). F. Physiol., Lond. 64, 215.

Folch, J., Lees, M. \& Stanley, G. H. S. (I957). F. biol. Chem. 226, 497.

Hooghwinkel, G. J. M., van Gelderen, H. N. \& Staal, A. (1969). Archs Dis. Childh. 44, I97.

Jacobs, M. H., Glassmann, H. N. \& Parpart, A. K. (1950). F. exp. Zool. 113. 277.

Lanzkowsky, P., McKenzie, D., Katz, S., Hoffenberg, R., Friedman, R. \& Black, E. (1967). Br. $\mathcal{Y}$. Haemat. 13, 639. 
Marinetti, G. V. (1962). F. Lipid Res. 3, 1.

Mönckeberg, F. (1968). In Calorie Deficiencies and Protein Deficiencies p. 9I [R. A. McCanceand E. M. Widdowson, editors]. London: J. \& A. Churchill Ltd.

Nye, W. H. R. \& Marinetti, G. V. (1967). Proc. Soc. exp. Biol. Med. 125, 1220.

Parker, F. \& Peterson, N. F. (1965). F. Lipid Res. 6, 455.

Pitcher, C. S. \& Williams, R. (1963). Clin. Sci. 24, 239.

Reed, C. F. (1959). F. clin. Invest. 38, 1032.

Roelofsen, B., Gier, J. de \& van Deenen, L. L. M. (1964). F. cell. comp. Physiol. 63, I.

Schwarz, K. \& Dean, R. F. A. (1957). F. trop. Pediat. 3, 23.

Staff, T. H. E. (I968). E. Afr. med. F. 45, 399.

van Deenen, L. L. M. (I965). Chem. Fats 8, 92.

Ways, P., Reed, C. F. \& Hanahan, D. J. (1963). F. clin. Invest. 42, 1248.

Zöllner, N. \& Wolfram, G. (1962). Klin. Wschr. 40, г гог. 